\title{
PERTUMBUHAN BAWANG MERAH (Allium cepa L.) YANG DIBERI PUPUK KOMPOS CAIR DAN JAMUR MIKORIZA ARBUSKULAR
}

\section{The Growth Of Red Onion (Allium cepa L.) Given Liquid Compost Fertilizer And Arbuscular Mycorrhizal Fungi}

\author{
Riska Anggraini Palesa*, Wahyu Harso
}

Jurusan Biologi Fakultas Matematika dan IImu Pengetahuan Alam Universitas Tadulako Tondo Palu, Sulawesi Tengah 94118

Keywords: Arbuscular Mycorrhizal Fungi, Liquid Compost and Red Onion
Kata Kunci: Bawang merah, Jamur mikoriza arbuskular dan Pupuk kompos cair.

\begin{abstract}
The application of liquid compost and of beneficial soil microorganism such as arbsucular mycorrhizal fungi can be used to replace chemical fertilizer application. The aim of this study was to investigate the growth of red onion (Allium cepa L.) plant fertilized by liquid compost and inoculated by arbuscular mycorrhizal fungi. This study was conducted based on a completely randomized design with two factors. The first factor was an addition of liquid compost dosages $(0,50,100$ and $200 \mathrm{ml} / \mathrm{polybag})$. The second factor was an addition of AM fungal inoculum (with and without addition). The results showed that the growth of red onion plant was not significantly affected by the addition of liquid compost and AM fungal inoculum. However, the red onion plant fertilized by $200 \mathrm{ml}$ liquid compost per polybag had the lowest shoot dry weight. The addition of AM fungal inoculum was not increasing plant growth because the quality of used inoculum was not good.
\end{abstract}

\section{ABSTRAK}

Penggunaan pupuk kompos cair dan mikoorganisme tanah berupa jamur mikoriza abuskular mampu meningkatkan kandungan unsur hara dan kesuburan tanaman. Penelitian ini bertujuan untuk mengurangi dampak penggunaan pupuk kimia yang akan mencemari lingkungan lingkungan maka pemberian hara terhadap tanaman harus dalam bentuk kompos yang relatif lebih ramah lingkungan. Selain itu untuk mempercepat proses penyerapan hara dari kompos maka digunakan kompos cair. Jamur mikoriza arbuskular akan membantu dalam proses peningkatan penyerapan hara. Penelitian ini dilakukan berdasarkan rancangan acak lengkap dengan dua faktor yaitu dosis pupuk kompos cair (0, 50, 100 dan $200 \mathrm{ml} /$ polybag) dan pemberian inokulum jamur mikoriza arbuskular (dengan pemberian inokulum dan tanpa pemberian inokulum). Hasil penelitian menunjukkan pemberian dosis pupuk kompos cair dan inokulum mikoriza tidak berpengaruh terhadap pertumbuhan tanaman bawang merah. Hal ini disebabkan karena terjadi proses pencucian hara dan kualitas inokulum yang tidak baik.

Corresponding Author : riskapalesa051@gmail.com 


\section{PENDAHULUAN}

Tanaman bawang merah (Allium cepa L.) merupakan salah satu komoditas tanaman holtikultura yang banyak dikonsumsi oleh masyarakat. Bawang merah memiliki nilai gizi dan ekonomi yang tinggi (Suriani, 2011). Saat ini Indonesia diduga sedang mengalami masalah pada distribusi bawang merah. Salah satu faktor penyebabnya adalah plot tanam yang hanya fokus pada beberapa daerah dan belum dikembangkannya daerah produksi baru. Produksi bawang merah tahun 2014 sebesar 1,234 juta ton. Hasil ini mengalami peningkatan sebesar 223,22 ribu ton atau 22,08\% dibandingkan dengan tahun 2013 dengan daerah penghasil tertinggi yaitu Jawa Tengah, Jawa Timur dan Jawa Barat. Peningkatan hasil produksi ini diperkirakan karena meningkatnya luas panen sebesar 21,77 ribu hektar atau 22,00\% (BPS, 2018). Potensi lahan pertanian di provinsi Sulawesi Tengah khususnya lembah Palu masih sangat luas untuk sayuran, termasuk bawang merah. Hal ini ditunjang dengan kondisi iklim yang kering dengan ketinggian 50 meter diatas permukaan laut dan jenis tanah latosol serta pengairan yang cukup (Putrasamedja dkk., 2004).

Salah satu faktor yang dapat mempengaruhi produksi bawang merah yaitu kondisi tanah yang kekurangan unsur hara akibat dari penggunaan tanah yang dilakukan secara terus menerus oleh petani.
Kondisi tanah yang seperti ini dapat mengurangi tingkat kesuburan serta menghambat pertumbuhan tanaman. Untuk mengatasi hal tersebut, dapat dilakukan dengan memanfaatkan mikroorganisme tanah berupa jamur mikoriza arbuskular dan penggunaan pupuk kompos cair. Penggunaan pupuk kompos cair diperlukan dalam penambahan unsur hara untuk menggantikan pupuk kimia yang memiliki dampak pada pencemaran lingkungan dan kesuburan tanah. Penggunaan kompos cair akan mempercepat proses pemupukan karena kompos sudah dalam keadaan terlarut. Kompos cair merupakan hasil ekstraksi dari kompos baik secara aerob maupun anaerob. Perbedaan pembuatan kompos tersebut akan menyebabkan perbedaan dalam jumlah dan jenis mikrooganisme tanah. Perbedaan keragaman mikroorganisme di dalam tanah dapat memberikan dampak positif atau netral terhadap produktifitas tumbuhan diatasnya (Widyati, 2013).

Jamur mikoriza arbuskular merupakan simbion akar yang ada disebagian besar ekosistem terestrial yang membentuk simbiosis mutualistik dengan tanaman (Lekberg et al., 2013). Jamur mikoriza memiliki peranan penting pada tanaman inangnya, yaitu mampu meningkatkan penyerapan mineral tanaman (seperti penyerapan $\mathrm{P}, \mathrm{N}$ dan mikronutrien) serta mampu membantu tanaman dalam 
penyerapan air (Hodge dan Storer, 2014), sehingga mampu meningkatkan

\begin{tabular}{cccccc}
\hline \multicolumn{2}{c}{$\begin{array}{c}\text { Dosis pupuk } \\
\text { kompos cair }\end{array}$} & K1 & K2 & K3 & K4 \\
\hline \multirow{2}{*}{ Mikoriza } & $\mathrm{M} 0$ & $\mathrm{~K} 1 \mathrm{M} 0$ & $\mathrm{~K} 2 \mathrm{M} 0$ & $\mathrm{~K} 3 \mathrm{MO}$ & $\mathrm{K} 4 \mathrm{M} 0$ \\
\cline { 2 - 6 } & $\mathrm{M} 1$ & $\mathrm{~K} 1 \mathrm{M} 1$ & $\mathrm{~K} 2 \mathrm{M} 1$ & $\mathrm{~K} 3 \mathrm{M} 1$ & $\mathrm{~K} 4 \mathrm{M} 1$ \\
\hline
\end{tabular}

\section{BAHAN DAN METODE}

Alat yang digunakan pada penelitian ini adalah alat tulis menulis, timbangan, ember, gelas ukur $1000 \mathrm{ml}$, ayakan $4 \mathrm{~mm}$, oven, neraca analitik, mistar/meteran, gunting stek, cangkul, penggaruk dan skop. Alat untuk pengamatan persentasi infeksi akar yaitu botol flakon (botol film), mikroskop dan petridish bergaris. Alat penentuan kadar phosfor daun yaitu gelas ukur, erlenmeyer, labu ukur, gelas kimia, pipet tetes, hot plate, mortar/penggerus, gelas piala dan spektofotometer.

Bahan yang digunakan adalah benih bawang merah (Allium cepa L.). Inokulum yang digunakan yaitu dari jenis Glomus deserticola,dan Glomus chlorum. Bahan pewarnaan infeksi mikoriza berupa Tryphan Blue, $10 \% \mathrm{KOH}$, asam laktat, $2 \mathrm{~N}$ $\mathrm{HCl}$ dan aquadest. Bahan penentuan kadar Phosphor dalam daun yaitu $\mathrm{H}_{2} \mathrm{O}_{2}, \mathrm{H}_{2} \mathrm{SO}_{4}$ pekat, aquadest, Amonium Molibdat, Kalium Antimonil Tratrat, Asam Askorbat dan $\mathrm{KH}_{2} \mathrm{PO}_{4}$. Pupuk yang digunakan berupa pupuk kompos cair serta beberapa bahan lainnya seperti, polybag $25 \mathrm{~cm} \times 30 \mathrm{~cm}$, spidol, karet, plastik tahan panas, lakban, pertumbuhan tanaman (Auge, 2001), perlindungan terhadap cekaman kekeringan (Rodriguez-Echeverria et al., 2009), patogen (Koske dan Poison 1984) dan toleransi terhadap tekanan biotik dan tekanan abiotik (Cavagnaro et al., 2001).

tissue dan label. spidol, karet, plastik tahan panas, tissue dan label.

Penelitian ini dilaksanakan dengan menggunakan metode Rancangan Acak Lengkap (RAL) dengan dua faktor yaitu :

$>$ Faktor pertama yaitu dosis pupuk kompos cair $(\mathrm{K})$

$\mathrm{K} 1: 0 \mathrm{ml} /$ polybag

$\mathrm{K} 2: 50 \mathrm{ml} /$ polybag

$\mathrm{K} 3: 100 \mathrm{ml} /$ polybag

K4 : $200 \mathrm{ml} /$ polybag

Faktor kedua yaitu mikoriza (M) M0 : tanpa inokulum jamur mikoriza arbuskular

M1 : dengan inokulum jamur mikoriza arbuskula 
Dari kedua faktor tersebut dapat diperoleh 8 unit kombinasi perlakuan dan masingmasing kombinasi perlakuan diulang sebanyak 4 kali. Unit perlakuan dapat dilihat pada tabel berikut :

Tabel 1. Unit Perlakuan

\section{Prosedur Kerja}

\section{- Penyiapan media tumbuh}

Media tumbuh diambil dari lapisan permukaan tanah sampai kedalaman 20 $\mathrm{cm}$ dicampur rata, kemudian dikeringanginkan selama 2 hari, lalu diayak menggunakan saringan ukuran $4 \times 4$ $\mathrm{mm}$. Tanah dimasukkan kedalam plastik tahan panas untuk disterilkan menggunakan oven pada suhu $80^{\circ} \mathrm{C}$ selama 48 jam. Setelah disterilisasi tanah didinginkan pada suhu ruang selama 24 jam, lalu dimasukkan kedalam polybag berukuran $25 \times 30 \mathrm{~cm}$ sebanyak $4 \mathrm{~kg}$.

\section{- Penentuan kapasitas lapang tanah}

Tanah diambil sebanyak 400 gram lalu dimasukkan kedalam wadah yang memiliki lubang pada bagian alasnya. Setelah itu, dimasukkan air kedalam wadah hingga wadah tergenang (jenuh) dan dibiarkan selama 48 jam. Air yang menetes dari wadah ditampung untuk diukur volumenya. Kapasitas lapang tanah merupakan hasil dari volume air yang dimasukkan kedalam wadah dikurangi dengan volume air yang menetes pada wadah penampung. Kapasitas lapang tanah dapat ditentukan dengan rumus :

$\mathrm{W}=\frac{(\mathrm{TB}-\mathrm{TK})}{\mathrm{TK}} \times 100 \%$

Keterangan :

W : Kadar air tanah

TB : Berat basah tanah

TK : Berat kering tanah

\section{- Penyiapan benih}

Bibit bawang merah yang digunakan adalah umbi yang telah disimpan selama 2 - 3 bulan, dan berasal dari tanaman yang dipanen pada usia 7-90 hari. Bagian ujung umbi terlebih dahulu dipotong sekitar $1 / 3-1 / 4$ bagian dari panjang umbi, dan kulit luar yang mengering dan sisa-sisa akar dibuang agar pertumbuhan umbi merata serta merangsang tumbuhnya tunas. Untuk mencegah pembusukan, sebelum ditanam, luka bekas potongan pada umbi harus dikeringkan terlebih dahulu.

\section{- Inokulasi}

Sebanyak $4 \mathrm{~kg}$ tanah steril dicampur secara homogen dengan inokulum jamur mikoriza didalam polybag sebanyak 20 gram/polybag untuk Glomus chlorum dan 20 gram/polybag Glomus deserticola.

\section{- Penanaman}

Umbi kemudian ditanam dalam polybag yang berisi media tumbuh tanah dengan kedalaman 2-3 cm dari atas permukaan. Umbi yang ditanam diberi air sampai 
mencapai $60 \%$ kapasitas lapang, selanjutnya polybag diletakkan kedalam rumah plastik.

\section{- Pembuatan Kompos Cair}

Untuk membuat kompos cair, dicampur sebanyak 500 gram kompos, $2000 \mathrm{ml}$ akuades dan gula secukupnya kemudian diaerasi dengan aerator selama 2 hari untuk kompos cair aerob (Harso, 2017). Kompos yang digunakan adalah kompos komersial.

\section{- Aplikasi Kompos Cair}

Pemupukan dengan kompos cair aerob dilakukan dengan cara disiram langsung pada media tanam dengan jumlah yang sesuai dengan perlakuan. Pemupukan pertama kali dilakukan saat tanaman berumur 1 minggu setelah tanam kemudian diulang kembali saat tanaman berumur 3 minggu.

\section{- Pemeliharaan}

Pemeliharaan tanaman dilakukan dengan perawatan tanaman, pengontrolan tanaman setiap hari dan penyiraman yang dilakukan dua hari sekali, dan secara bersamaan tata letak polybag diubah secara acak.

\section{- Pemanenan}

Pemanenan dilakukan saat tanaman berumur 35 hari setelah penanaman berlangsung.

\section{- Parameter pengamatan}

1) Berat basah tajuk dan akar tanaman
Berat basah tajuk dan akar dilakukan dengan cara menimbang berat segar tanaman setelah dipanen.

2) Berat kering tajuk dan akar tanaman Tanaman dibersihkan dari tanah yang menempel, lalu dikeringkan dalam oven pada suhu $65^{\circ} \mathrm{C}$ hingga berat keringnya konstan kemudian ditimbang.

3) Persentase akar yang terinfeksi oleh jamur mikoriza

Persentase akar yang terinfeksi jamur ditentukan dengan pengecatan akar dengan menggunakan metode Phillip and Hayman (1970) yang telah dimodifikasi. Secara acak diambil 0,5 gram akar segar kemudian akar tersebut dibersihkan dengan air mengalir dan akar dipotong-potong dengan ukuran kurang lebih $1 \mathrm{~cm}$. Kemudian akar dijernihkan dengan merendam potongan akar pada larutan $\mathrm{KOH} 10 \%$ selama 25 menit pada temperatur $60^{\circ} \mathrm{C}$ dalam oven. Kemudian potongan akar direndam dalam larutan $2 \mathrm{~N} \mathrm{HCl}$ selama 2 menit. Setelah direndam dalam $\mathrm{HCl}$, kemudian akar diwarnai dengan merendam akar dalam larutan tryphan blue $0,05 \%$ tryphan blue dalam asam laktat) selama 20 menit pada suhu $60^{\circ} \mathrm{C}$. Potongan akar selanjutnya dimasukkan ke dalam botol flakon (botol film) yang telah diisi asam 
laktat. Setelah 12 jam direndam dalam asam laktat maka akar siap untuk diamati dibawah mikroskop. Jumlah akar yang terkolonisasi dihitung menggunakan Gridline intersec method (Giovanetti dan Mosse, 1980) yaitu akar yang telah diwarnai, diambil secara acak, dipotong sepanjang $1 \mathrm{~cm}$, lalu disusun secara acak pada petridish bergaris. Persentase akar yang terinfeksi dihitung menggunakan rumus :

$\% \mathrm{AT}=\frac{\sum \mathrm{AT}}{\sum \mathrm{AD}} \times 100 \%$

Keterangan :

AT : Aakar Terinfeksi

AD : Akar yang Diamati

4) Kadar P (Phosphor) dalam tajuk Pengukuran kadar $P$ dalam daun dilakukan dengan metode dekstruksi basah menurut Nusantara (2002) yang telah dimodifikasi. Tajuk didestruksi (hancurkan) secara basah terlebih dahulu menggunakan mortar/penggerus. Sebanyak 0,25 gram tajuk yang sudah dihaluskan dimasukkan kedalam labu ukur $50 \mathrm{ml}$. Kemudian ditambahkan 2,5 $\mathrm{ml} \mathrm{H}_{2} \mathrm{SO}_{4}$ pekat (b. j. 1,84) dan dibiarkan semalam. Keesokan harinya dipanaskan selama 15 menit pada suhu rendah. Kemudian suhu dinaikkan sedikit demi sedikit hingga kurang lebih $150^{\circ} \mathrm{C}$. Setelah kira-kira
30 menit ditambahkan 5 tetes $\mathrm{H}_{2} \mathrm{O}_{2}$ $30 \%$ dalam selang waktu 10 menit. Pemberian $\mathrm{H}_{2} \mathrm{O}_{2}$ dilakukan berulangulang hingga cairan dalam labu ukur menjadi jernih. Setelah itu dipanaskan pada suhu $250^{\circ} \mathrm{C}$ sampai cairan yang tertinggal $2,5 \mathrm{ml}$. Setelah didinginkan diencerkan dengan aquades sampai tanda garis. Ekstrak dikocok, disaring dan dicampur dalam erlenmeyer 100 $\mathrm{ml}$. Diambil sebanyak $5 \mathrm{ml}$ cairan ini menggunakan pipet tetes dan dimasukkan ke dalam labu ukur $50 \mathrm{ml}$ dan diencerkan dengan akuadest. Dari cairan ini ditetapkan kadar P.

Prosedur Penetapan Kadar $\mathrm{P}$ (Pembuatan reagen $\mathrm{P}$ dilakukan dengan menambahkan $50 \mathrm{ml} \mathrm{H}_{2} \mathrm{SO}_{4}$ $5 \mathrm{~N}+15 \mathrm{ml}$ ammonium molibdat +5 $\mathrm{ml}$ kalium antimonil trartrat $+30 \mathrm{ml}$ asam askorbat kemudian dijadikan $500 \mathrm{ml}$ dengan menambahkan akuades. Hasil destruksi basah diambil sebanyak 2,5 $\mathrm{ml}$ dan dimasukkan ke dalam tabung reaksi. Ditambahkan reagen $P$ sebanya 10 $\mathrm{ml}$ dan dikocok dengan hati-hati. Ditentukan nilai absorbansi larutan tersebut dengan spektrofotometer UV VIS pada panjang gelombang 693 $\mathrm{nm}$. Kemudian dihitung kadar $\mathrm{P}$ dalam larutan tersebut dengan menggunakan kurva standar atau garis regramesi yang telah disiapkan 
sebelumnya. Kadar $\mathrm{P}$ dalam persen ditentukan dengan menggunakan rumus :

$\% \mathrm{P}=\frac{0,2 \mathrm{ppm} \mathrm{P} \text { dari kurva setelah dikoreksi }}{\text { Blanko }}$

Pembuatan kurva standar $\mathrm{P}$

Sebanyak 2,1952 gram $\quad \mathrm{KH}_{2} \mathrm{PO}_{4}$ kering ditimbang. Dibuat larutan standar $\mathrm{KH}_{2} \mathrm{PO}_{4}$ yang telah dikeringkan selama 2 jam pada temperature $105^{\circ} \mathrm{C}$ dan ditimbang seberat 2,1952 gram. Kemudian dilarutkan menggunakan aquades sampai larutan menjadi $1000 \mathrm{ml}(1 \mathrm{~L})$ yang mengandung $500 \mathrm{ppm}$ larutan standar. Dari 500 ppm larutan standar kemudian di ambil menggunakan pipet sebanyak $10 \mathrm{ml}$ dan diencerkan dengan menggunakan $0,1 \mathrm{~N} \mathrm{H}_{2} \mathrm{SO}_{4}$ sehingga volume menjadi $100 \mathrm{ml}$. Larutan ini mengandung $50 \mathrm{ppm}$ larutan standar. Dibuat deret standar $\mathrm{P}$ dari larutan 50 ppm sebagai berikut:

\section{HASIL DAN PEMBAHASAN}

Berat basah tajuk tanaman uji tidak dipengaruhi oleh pemberian inokulum jamur mikoriza arbuskular. Berat basah tajuk dipengaruhi oleh konsentrasi pemberian pupuk kompos cair. Berat basah tajuk tertinggi terdapat pada konsentrasi pupuk kompos cair $0 \mathrm{ml} /$ polybag terutama pada tanaman yang tidak diberi inokulum mikoriza meskipun tidak berbeda nyata
Tabel 2. Penambahan aquades

\begin{tabular}{cc}
\hline Kadar $\mathbf{P}$ & $\begin{array}{c}\text { Larutan yang } \\
\text { ditambahkan }\end{array}$ \\
\hline 0 & $0 \mathrm{ml}$ \\
\hline 0,5 & $0,5 \mathrm{ml}$ \\
\hline 1 & $1 \mathrm{ml}$ \\
\hline 2 & $2 \mathrm{ml}$ \\
\hline 3 & $3 \mathrm{ml}$ \\
\hline 4 & $4 \mathrm{ml}$ \\
\hline 5 & $5 \mathrm{ml}$ \\
\hline masing-masing volume dijadikan & 10
\end{tabular}

$\mathrm{ml}$ dengan menambahkan aquades.

\section{Analisis Data}

Data yang diperoleh kemudian dianalisis dengan menggunakan two ways anova dengan menggunakan program software SPSS. Kemudian diuji lanjut dengan menggunakan DMRT pada taraf uji $5 \%$.

terhadap pemberian pupuk cair dengan konsentrasi 50 dan $100 \mathrm{ml} /$ polybag. Pada perlakuan $200 \mathrm{ml} /$ polybag tanaman uji cenderung memiliki berat basah tajuk terendah (gambar 4.1). Tidak terjadi interaksi antara mikoriza dan pupuk kompos cair terhadap berat basah tajuk tanaman uji. 


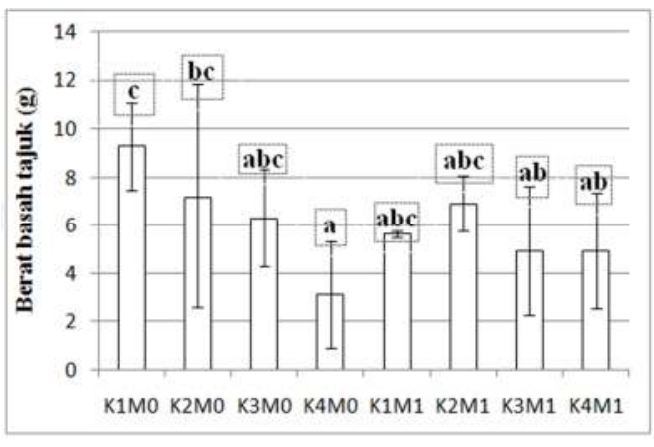

Gambar 1. Berat basah tajuk bawang merah (Allium cepa L.) yang diberi pupuk kompos cair dengan konsentrasi $0 \mathrm{ml} /$ polybag (K1), 50 $\mathrm{ml} /$ polybag (K2), $100 \mathrm{ml} /$ polybag (K3) dan 200 $\mathrm{ml} /$ polybag (K4) dengan tanpa inokulum jamur mikoriza arbuskular (M0) dan dengan inokulum jamur mikoriza arbuskular (M1) umur 36 hari setelah tanam. Nilai yang diberikan adalah nilai rata-rata \pm standar deviasi. Batang grafik yang diikuti oelh huruf yang sama menunjukkan hasil yang tidak berbeda nyata pada taraf uji $5 \%$.

Berat kering tajuk tanaman uji tidak dipengaruhi oleh pemberian inokulum jamur mikoriza arbuskular. Konsentrasi pupuk kompos cair juga tidak memberikan pengaruh terhadap berat kering tajuk tanaman uji. Tanaman uji yang diberi pupuk cair dengan konsentrasi 200 ml/polybag cenderung memiliki berat kering tajuk terendah (gambar 4.2). Tidak terdapat interaksi antara inokulum jamur mikoriza arbuskular dan konsentrasi pupuk kompos cair terhadap berat kering tajuk tanaman uji.

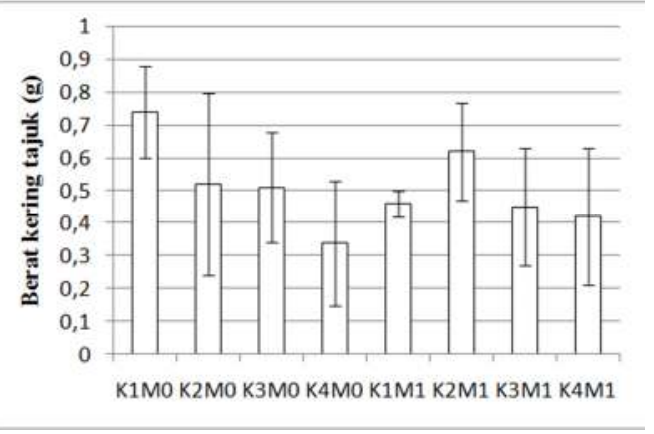

Gambar 2. Berat kering tajuk bawang merah (Allium cepa L.) yang diberi pupuk kompos cair dengan konsentrasi 0 $\mathrm{ml} /$ polybag (K1), $50 \mathrm{ml} /$ polybag (K2), 100 $\mathrm{ml} /$ polybag (K3) dan $200 \mathrm{ml} /$ polybag (K4) dengan tanpa inokulum jamur mikoriza arbuskular (M0) dan dengan inokulum jamur mikoriza arbuskular (M1) umur 36 hari setelah tanam. Nilai yang diberikan adalah nilai rata-rata \pm standar deviasi.

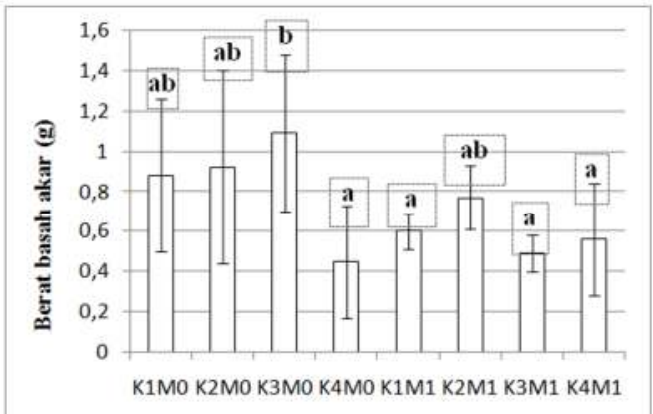

Gambar 3. Berat basah akar bawang merah (Allium cepa L.) yang diberi pupuk kompos cair dengan konsentrasi $0 \mathrm{ml} /$ polybag (K1), 50 $\mathrm{ml} /$ polybag (K2), $100 \mathrm{ml} /$ polybag (K3) dan 200 $\mathrm{ml} /$ polybag (K4) dengan tanpa inokulum jamur mikoriza arbuskular (M0) dan dengan inokulum jamur mikoriza arbuskular (M1) umur 36 hari setelah tanam. Nilai yang diberikan adalah nilai rata-rata \pm standar deviasi. Batang grafik yang diikuti oelh huruf yang sama menunjukkan hasil yang tidak berbeda nyata pada taraf uji $5 \%$.

Berat basah akar tanaman uji tidak dipengaruhi oleh konsentrasi pupuk kompos cair. Berat basah akar tanaman uji cenderung lebih rendah pada tanaman yang diberi inokulum jamur mikoriza arbuskular 
(gambar 4.3). Tidak terdapat interaksi antara inokulum jamur mikoriza arbuskular dan konsentrasi pupuk kompos cair terhadap berat basah akar tanaman uji.

Pemberian inokulum jamur mikoriza arbuskular dan konsentrasi pupuk kompos cair tidak berpengaruh terhadap berat kering akar tanaman uji. Tidak terdapat interaksi antara pupuk kompos cair dan inokulum jamur mikoriza arbuskular terhadap berat kering akar tanaman uji (gambar 4).

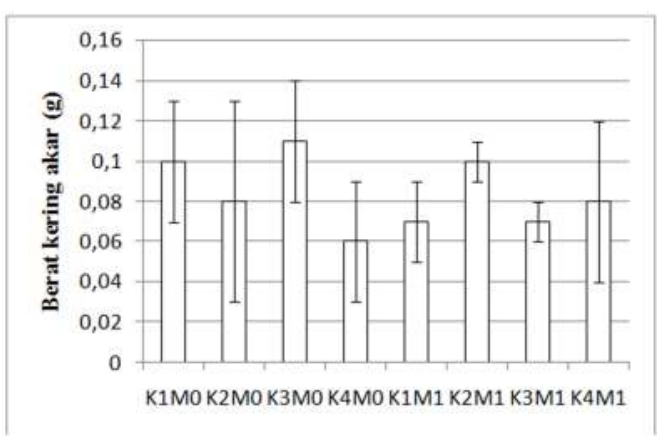

Gambar 4. Berat kering akar bawang merah (Allium cepa L.) yang diberi pupuk kompos cair dengan konsentrasi $0 \mathrm{ml} /$ polybag (K1), 50 $\mathrm{ml} /$ polybag (K2), $100 \mathrm{ml} /$ polybag (K3) dan 200 $\mathrm{ml} /$ polybag (K4) dengan tanpa inokulum jamur mikoriza arbuskular (M0) dan dengan inokulum jamur mikoriza arbuskular (M1) umur 36 hari setelah tanam. Nilai yang diberikan adalah nilai rata-rata \pm standar deviasi.

Pemberian inokulum jamur mikoriza arbuskular dan konsentrasi pupuk kompos cair tidak memberikan pengaruh terhadap kadar fosfor dalam tajuk tanaman uji. Tidak terdapat interaksi interaksi antara inokulum jamur mikoriza arbuskular dengan konsentrasi pupuk kompos cair terhadap kadar fosfor dalam tajuk tanaman uji.

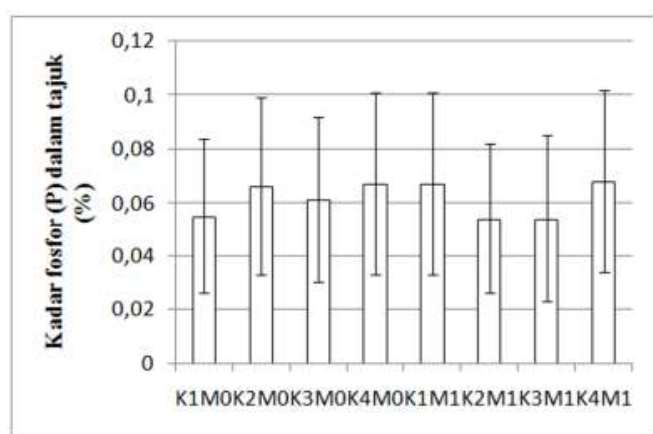

Gambar 5. Kadar fosfor $(P)$ pada tajuk bawang merah (Allium cepa L.) yang diberi pupuk kompos cair dengan konsentrasi $0 \mathrm{ml} /$ polybag (K1), $50 \mathrm{ml} /$ polybag (K2), $100 \mathrm{ml} /$ polybag (K3) dan $200 \mathrm{ml} /$ polybag (K4) dengan tanpa inokulum jamur mikoriza arbuskular (M0) dan dengan inokulum jamur mikoriza arbuskular (M1) umur 36 hari setelah tanam. Nilai yang diberikan adalah nilai rata-rata \pm standar deviasi.

Pada penelitian ini tanaman dengan tanpa pemberian pupuk (0 ml/polybag) cenderung tumbuh lebih baik dibandingkan dengan tanaman yang diberikan pupuk kompos cair, dengan melihat parameter dari berat kering tajuk yang diukur. Tanaman bawang yang diberi pupuk kompos cair dengan konsentrasi $200 \mathrm{ml} /$ polybag cenderung memiliki berat kering tajuk terendah. Kurangnya pengaruh pupuk kompos cair pada penelitian ini mungkin disebabkan salah satunya oleh kelebihan unsur hara $P$. Fosfor merupakan unsur hara makro esensial yang dibutuhkan tanaman untuk pembentukan sel pada jaringan akar dan tunas yang sedang tumbuh serta memperkuat batang (Aleel, 2008). Semakin tinggi dosis pupuk kompos cair yang diberikan pertumbuhan tanaman cenderung semakin rendah. Hal ini menunjukkan bahwa dosis pupuk yang diberikan melebihi 
dosis optimal yang diperlukan untuk pertumbuhan tanaman bawang merah. Kebutuhan unsur hara pada tanaman bawah merah cenderung lebih rendah dari tanaman lain seperti jagung.

Menurut Sumarni dkk. (2012) dosis pupuk $\mathrm{P}$ 92-126 kg/ha merupakan dosis optimal untuk pertumbuhan tanaman bawang merah. Sedangkan pada tanaman jagung dosis optimal pupuk $P$ yaitu $150-240 \mathrm{~kg} / \mathrm{ha}$ (Herlina dkk, 2018 dan La Habi, 2012). Dosis optimal pupuk $\mathrm{P}$ pada tanaman jagung lebih tinggi dibandingkan dengan dosis optimal pupuk $\mathrm{P}$ pada tanaman bawang merah. Akan tetapi kandungan unsur hara tanah pada penelitian ini tidak dilakukan pengukuran.

Pemberian unsur hara $P$ yang melebihi kebutuhan tanaman dapat menghambat pertumbuhan tanaman, bahkan pada tingkat dosis yang lebih tinggi akan menyebabkan kematian tanaman (Liferdi, 2010). Meskipun pada penelitian ini konsentrasi fosfor pada tanaman tidak dipengaruhi oleh konsentrasi pupuk kompos cair dan pemberian inokulum jamur mikoriza arbsukular.

Tanaman yang diinokulasikan dengan jamur mikoriza arbuskular cenderung memiliki kandungan fosfor (P) lebih tinggi dibandingkan dengan tanaman yang tidak bermikoriza. Hal ini karena mikoriza memiliki hifa yang dapat membantu akar untuk menjangkau unsur hara yang sulit dijangkau oleh akar (Musfal, 2010). Mikoriza juga mampu meningkatan berat segar dan berat kering tanaman serta meningkatkan serapan air dan unsur hara baik unsur hara makro maupun mikro (Nasaruddin, 2012).

Efektivitas jamur mikoriza arbuskular dipengaruhi oleh kesesuaian jenis genotip tanaman, suhu, media tanam, lama penyimpanan dan daya kecambah. Lama penyimpanan akan menyebabkan menurunnya kualitas spora jamur mikoriza sehingga mempengaruhi daya infeksinya pada tanaman inang (Smith dan Read, 2008). Inokulum yang digunakan pada penelitian ini merupakan inokulum yang telah disimpan selama kurang lebih 10 bulan. Setiap inokulum jamur mikoriza arbuskular memiliki daya simpan yang berbeda-beda. Menurut Astiko (2008), jamur mikoriza arbuskular jenis Glomus clorum hanya dapat disimpan selama 4 bulan. Setelah melewati waktu tersebut inokulum akan menampakkan gejala penurunan viabilitasnya yaitu dengan menurunnya kemampuan infeksi pada tanaman inang. Menurunnya daya infeksi tersebut akan mempengaruhi efektivitas mikoriza pada tanaman inang.

\section{SIMPULAN}

Pemberian inokulum jamur mikoriza arbuskula tidak meningkatkan pertumbuhan tanaman bawang merah disebabkan kualitas inokulum yang sudah tidak baik. Pemberian pupuk kompos cair sebanyak 
$200 \mathrm{ml} /$ ploybag cenderung akan menghambat pertumbuhan tajuk tanaman bawang merah.

\section{DAFTAR PUSTAKA}

Aleel, K.G. 2008. Phosphate Accumulation in Plant: Signaling. Plant Physiol, 148, 3-5.

Astiko, W. 2008. Kesesuaian Jenis Kemasan, Suhu, dan Lama Penyimpanan Inokulum Komersial Jamur Mikoriza Tanah Vertisol Lombok. CropAgro, 2, 144-150.

Auge RM .2001. Water relations, drought and vesicular arbuscular mycorrhizal symbiosis. Journal Mycorrhiza, 11, 324.

[BPS] Badan Pusat Statistik. 2018. Produksi Cabai Besar, Cabai rawit dan Bawang Merah. Diperoleh dari website Badan Pusat Statistik: https://www.bps.go.id. Diakses 10 September 2018.

Cavagnaro TR, Gao LL, Smith FA, Smith SE. 2001. Morphology of arbuscular mycorrhizas is influenced by fungal identity. Journal New Phytol, 151, 469-475.

Giovannetti, M., and Mosse, B. 1980. An evaluation of techniques for measuring vesicular arbuscular mycorrhizal infection in roots. Journal New Phytol, 84, 489-500.

Harso, W. 2017. Pengaruh Pemberian Kompos padat dan Kompos Cair Terhadap Pertumbuhan Tanaman yang Ditumbuhkan pada Media Tanah atau Gambut. Natural Science: Journal of Science and Technology, 6(1), 83-89.

Herlina, M.P., Yunus, A., Harjoko, D. 2018. Dosis Pupuk Fosfat Terhadap Pertumbuhan dan Hasil Beberapa
Jagung Hibrida. Agrosains, 20(2), 3439.

Hodge, A, Storer, K .2014. Arbuscular mycorrhizal and nitrogen: implications for individual plants through to ecosystems. Journal Plant Soil, 386, 1-19.

Koske RE, Poison WR .1984. Are VA mycorrhizae required for sand dune stabilization?. Journal Bioscience, 34, 420-424.

La Habi, M. 2012. Ketersediaan Fosfat, Serapan Fosfat dan Hasil Tanaman Jagung Akibat Pemberian Bokashi Ela Sagu dengan Pupuk Fosfat pada Inceptisols. Buana Sains, 12(1), 6370.

Lekberg Y, Gibbons SM, Rosendahl S, Rawsey PW .(2013). Severe plant invasions can increase mycorrhizal fungal abundance and diversity. Journal ISME J, 7,1423-1433.

Liferdi, L. 2010. Efek Pemberian Fosfor Terhadap Pertumbuhan dan Status Hara pada Bibit Manggis. J. Hort, 20(1), 18-26.

Nasaruddin. 2012. Respon Pertumbuhan Bibit Kakao Terhadap Inokulasi Azotobacter dan Mikoriza. Agrivigor, 11(2), 300-315.

Nusantara, D.A., 2002. Tanggap semai sengon (Paraserianthes falcataria $\mathrm{L}$. Nielsen) terhadap inokulasi ganda cendawan mikoriza arbuskular dan Rhizobium sp. J. Ilmu-IImu Pertanian Indonesia, 22(4), 62-70.

Musfal. 2010. Potensi Cendawan Mikoriza Arbuskular untuk Meningkatkan Hasil Tanaman Jagung. Litbang Pertanian, 29(4), 154-158.

Phillip, J.M. and Hayman, D.S., 1970. Improved procedurres for clearing 
roots staining parasitics and VAM fungi for rapid accesment of infection. Journal Trans Brit Mycol Soc, 46(2), 235-244.

Putrasamedja, S., Suryadi, dan Maskar. 2004. Evaluasi Pertumbuhan Dan Daya Hasil Enam Klon Bawang Merah Di Dataran Rendah Donggala. Pembangunan Pedesaan, 4(3), 157158.

Rodriguez-Echeverria S, Crisóstomo JA, Nabais C, Freitas H. 2009. Belowground mutualists and the invasive ability of Acacia longifolia in coastal dunes of Portugal. Journal Biol Invasions, 11, 651-661.

Smith, S. E and Read, DJ. 2008. Mycorrhizal symbiosis. New York: Academic Press.
Sumarni, N., Rosliani, R., Basuki, RS., Hilman, Y. 2012. Respons Tanaman Bawang Merah Terhadap Pemupukan Fosfat pada Beberapa Tingkat Kesuburan Lahan (Status P-Tanah). J. Hort, 22(2), 129-137.

Sumarni, N., Rosliani, R., Suwandi. 2012. Optimasi Jarak Tanam dan Dosis Pupuk NPK untuk Produksi Bawang Merah dari Benih Umbi Mini di Dataran Tinggi. J. Hort, 22(2), 147154.

Suriani, N. 2011. Bawang bawa untung. Budidaya bawang merah dan bawang putih. Yogyakarta: Cahaya Atma Pustaka.

Widyati, E. 2013. Pentingnya Keragaman Fungsional Organisme Tanah Terhadap Produktivitas Lahan. Tekno Hutan Tanaman, 6(1), 29-37. 